\title{
Ethno-Veterinary Traditional Knowledge of Some Plants Used in Wardha district (Maharashtra)
}

\author{
Arati Pranjale, K. G. Dube \\ Post Graduate Department of Botany, Jankidevi Bajaj College of Science, Wardha-442001(India)
}

\begin{abstract}
Most of the rural peoples in Wardha district, especially having low income rear livestock on diet consisting of high quantities of locally available indigenous fodder plants. In rural areas modern veterinary services are not available and also affordable to the villagers. Hence the small holder farmers and labors rely on traditional knowledge to cure their goats. The present study was conducted to explore traditional knowledge used for treating common diseases of Goats. A questioner was structured for this research work and interviewed the farmers, shepherds and vaidus asking the plants used to treat specific veterinary diseases and their mode of treatment. The documented information showed that about 28 medicinal plants categorized as Trees (13), Shrubs (4) Herbs (4), Climbers (4), Twiners (2) and Bulb (1)were used by villagers. Mostly plants were used for diseases like Enteritis, Maggot wound, Fracture, Tympani, Black quarter and few others. The present paper deals with the ethno-veterinary aspects of these traditional wild fodder plants.
\end{abstract}

Keywords: Ethno-veterinary, Traditional knowledge, diseases of goats, Wardha district

\section{Introduction}

Peoples are using different plants for curing the diseases of cattle's since ancient times. Even during present times, many villagers from developing countries follow same traditional practices. These practitioners have valuable knowledge about many plants being used to heal the diseases of goats. However, their knowledge is not made available due to lacuna of scientific documentation and ethno-veterinary research which includes indigenous knowledge and its related skills, practices and social beliefs belonging to animal healthcare for income generation [1]

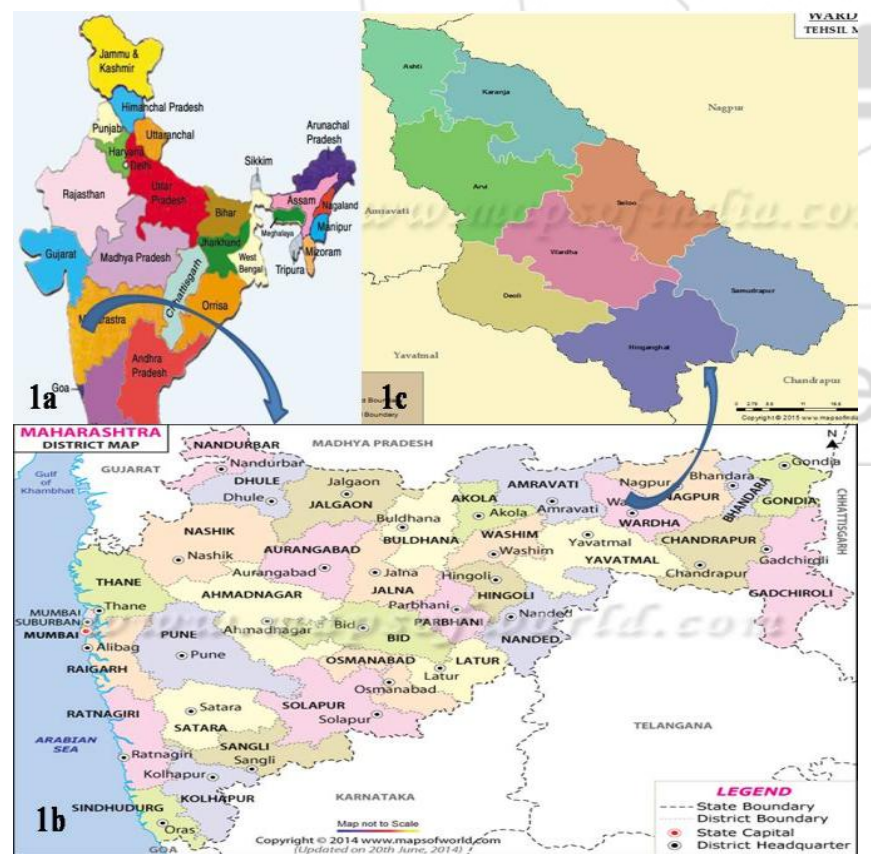

Figure 1: Maps of India (a), Maharashtra (b) and Wardha district (c)

In Wardha district, $67.45 \%$ of population is located in rural areas [2]. Most of them are farm labourers and marginal land holders [3]. Other than farming, cattle's rearing is a promising and sustainable source for their livelihood. As per census 2014, total livestock of Wardha district is
6,10,532 animals of which goat and sheep comprises 31.8 $\%$. This large population depends on available natural vegetation, which is decreasing alarmingly for want of proper knowledge and conservation by the community. So, the present researcher have made an attempt to document traditional knowledge available with shepherds, vaidus and elder villagers from the various parts of Wardha district so as to help them in appropriate utilization of valuable medicinal plants and their conservation. The present paper is the part of same investigation, which deals with the ethnoveterinary aspects of these plants.

\section{Literature Survey}

Patil et al. (2010) reported 80 species from 44 families were applied as veterinary medicine out of which 29 species exclusively marked for ethno-veterinary purpose [4]. Malla and Chhetri (2012) studied 21 plants belonging to 19 families for common diseases like foot and mouth disease, wounds and bone fracture [1]. Shrivastava et al. (2012) while studying herbal medicines used in treatment of goats in and around Gwalior documented Azadirachta indica and Allium sativum were used on most of the diseases [5] Panda and Dhal (2014) reported 48 plants used as ethnoveterinary medicines in Nawrangpur, Odisha, Nepal were Azadirachta indica, Vitex negundo, Semecarpus anacardium were common [6]. Patil and Deshmukh (2015) studied the traditional ethno-veterinary practices in Betul, (M.P.) and recorded 41 species of plants belonging to 32 familes in which Fabaceae, Caesalpiniaceae, Solanaceae, Cucurbitaceae and Asclepediaceae were dominant [7]

\section{Methods /Approach}

The rural peoples are dependent on forest and natural vegetation for their daily requirements. Therefore present research was focused in 34 villages nearby forest areas from Arvi, Ashti, Deoli, Hinganghat, Karanja, Seloo and Samudrapur tehsils of Wardha district. The detailed survey and interviews of 79 shepherds, vaidus and livestock owner's in person and in group discussion were conducted. The study was concentrated on documentation of the usage 


\section{International Journal of Science and Research (IJSR) \\ ISSN (Online): 2319-7064 \\ Index Copernicus Value (2013): 6.14 | Impact Factor (2015): 6.391}

of plants for healing goats. Field visits were conducted with voucher specimen.

shepherds to identify plant species and to collect their

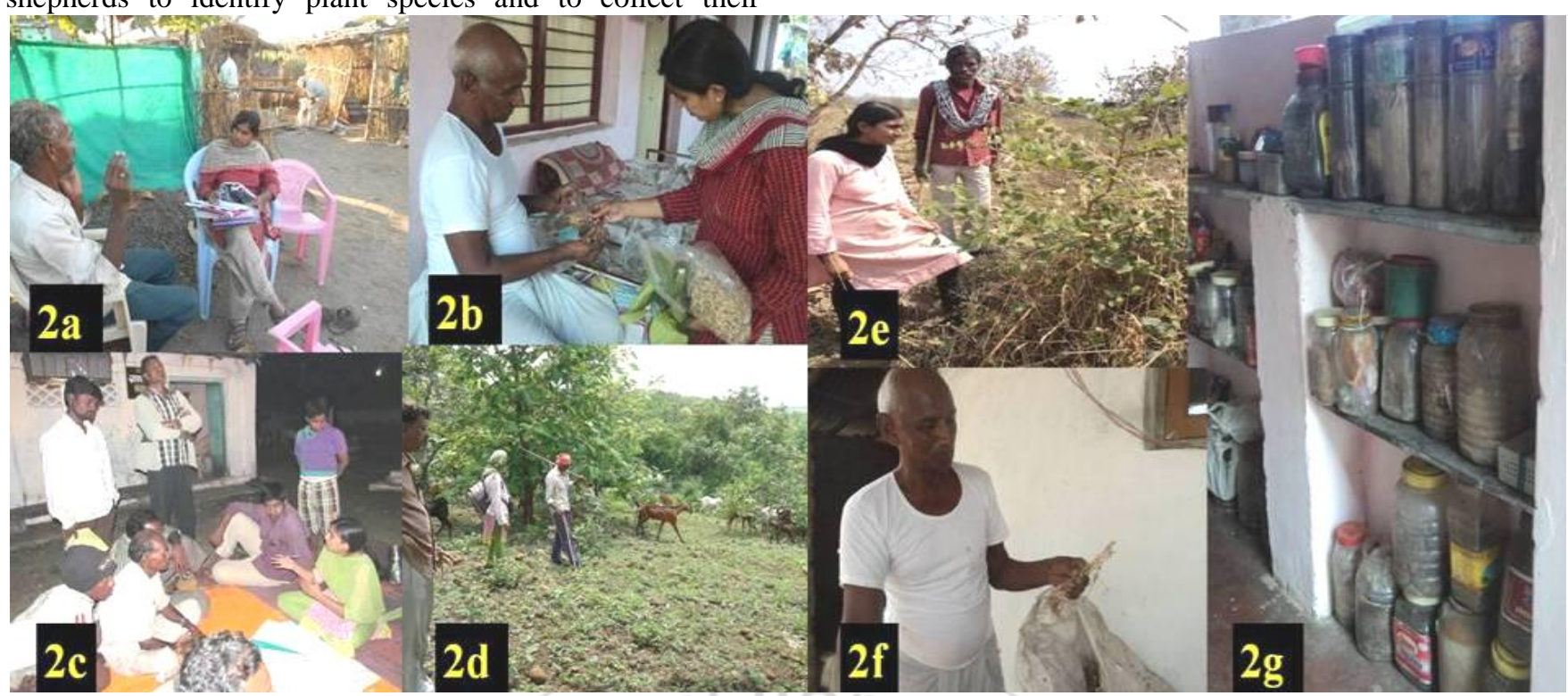

Figure 2: Personal interview with villagers $(a, b)$, Group discussion with shepherds $(c)$, Field visits in the forests (d, e),

Traditional storage of plant parts (f. g).

Plant species recorded by rural peoples as ethno-veterinary practices, were enumerated with botanical name and family in parenthesis, vernacular name, habit, useful parts, used for specific disease and their mode of treatment. These plants were identified using the Flora of Maharashtra [8], [9].

\section{Results / Discussion}

The data about ethno-veterinary plants used for treatment of goats have been enumerated in Table 1 and Figs. 3-5. About 28 common plants were used as herbal remedies which were categorized as Trees (13), Shrubs (4) Herbs (4), Climbers (6) and Bulb (1). They belonged to 24 families including Amaryllidaceae, Anacardiaceae, Asclepiadaceae,
Balanitacaceae, Boraginaceae, Cactaceae, Caesalpinaceae, Colchicaceae, Convolvulaceae, Cucurbitaceae, Euphorbiaceae, Fabaceae, Linaceae, Malvaceae, Meliaceae, Myrtacae, Periplocaceae, Rhamnaceae, Rutaceae, Sapotaceae, Simaroubaceae, Solanaceae, Verbeanacae and Zingiberacae. These 28 plants were useful for curing 17 types of diseases like Enteritis, Anthrax, Black quarter, Conjunctivitis, Dysentry, Maggoted wound, Fracture, Tympani, Hemorrhagic septicemia, Mouth and Foot diseases, Pneumonia, Sunstroke, Wounds, Galse, Pankawse $\&$ Mowase. The percentage of plant parts used as medicine was as: Leaves (38\%), Bark and Fruits (16\%), Rhizome $(9 \%)$, Stem $(6 \%)$, Flowers $(6 \%)$, Seeds $(6 \%)$ and Bulb $(3 \%)$.

Table 1: Ethno-veterinary plants

\begin{tabular}{|c|c|c|c|c|c|c|}
\hline $\begin{array}{l}\text { Sr. } \\
\text { No. }\end{array}$ & $\begin{array}{l}\text { Scientific name } \\
\text { and Family }\end{array}$ & $\begin{array}{l}\text { Local } \\
\text { name }\end{array}$ & Habit & $\begin{array}{c}\text { Useful } \\
\text { plant } \\
\text { part }\end{array}$ & $\begin{array}{l}\text { Diseases for } \\
\text { which used }\end{array}$ & Mode of treatment \\
\hline 1 & Ailanthus excelsa Roxb. Simaroubaceae & Maharukh & Tree & Bark & Enteritis & Leaves given to eat \\
\hline 2 & $\begin{array}{c}\text { Allium sativum Linn. } \\
\text { Amaryllidaceae }\end{array}$ & Lasun & Bulb & Bulb & Pneumonia & Oil from heated bulb is dropped in nose \\
\hline 3 & $\begin{array}{l}\text { Azadiracta indica A.Juss. } \\
\text { Meliaceae }\end{array}$ & Kadunimb & Tree & $\begin{array}{l}\text { Bark, } \\
\text { Leaves }\end{array}$ & Sunstroke & $\begin{array}{c}\text { Decoction of leaves or Juice of internal } \\
\text { bark is given }\end{array}$ \\
\hline 4 & $\begin{array}{c}\text { Balanites aegytiaca (Linn.) Del. } \\
\text { Balanitaceae }\end{array}$ & Hinganbet & Tree & Fruits & $\begin{array}{l}\text { Trypano- } \\
\text { somiasis }\end{array}$ & Crushed fruit applied on head \\
\hline 5 & Boswellia serrata Roxb Boraginacaceae & Salai & Tree & Leaves & Pankawse & Crushed leaves gives with buttermilk \\
\hline 6 & $\begin{array}{c}\text { Butea monosperma (Lamk.) } \\
\text { Fabaceae }\end{array}$ & Palas & Tree & \begin{tabular}{|l|} 
Bark, \\
leaves, \\
Flowers \\
\end{tabular} & $\begin{array}{l}\text { Fracture, } \\
\text { Anthrax }\end{array}$ & $\begin{array}{l}\text { Bark binded to fractured part, Paste of } \\
\text { flowers applied externally }\end{array}$ \\
\hline 7 & $\begin{array}{l}\text { Caesalpinia decapetala (Rothl) } \\
\text { Caesalpiniaceae }\end{array}$ & Sagargoti & Shrub & Leaves & Enteritis & Leaves given to eat \\
\hline 8 & $\begin{array}{c}\text { Choroxylon swietenia DC. } \\
\text { Rutaceae }\end{array}$ & Bhera & Tree & Leaves & Mowasa & Leaf juice applied on mouth \\
\hline 9 & $\begin{array}{c}\text { Citrus aurantifolia (Christm.) } \\
\text { Rutaceae }\end{array}$ & Limbu & Tree & Fruits & Tympani & Pickle of fruits given to eat \\
\hline 10 & Cryptolepis buchananii $\quad$ R. \& S. Periplocaceae & Dudhi & Climber & Fruits & $\begin{array}{c}\text { Black quarter, } \\
\text { Pneumonia }\end{array}$ & Boiled soup of fruit given to drink \\
\hline 11 & $\begin{array}{l}\text { Curcuma longa } \mathrm{L} . \\
\text { Zingiberaceae }\end{array}$ & Halad & Herb & Rhizome & \begin{tabular}{|c|} 
Wounds, \\
Hemorr-hagic \\
septicmia
\end{tabular} & $\begin{array}{l}\text { Rhizome powder applied on wounds \& } \\
\text { given with water to drink }\end{array}$ \\
\hline
\end{tabular}




\section{International Journal of Science and Research (IJSR) \\ ISSN (Online): 2319-7064}

Index Copernicus Value (2013): 6.14 | Impact Factor (2015): 6.391

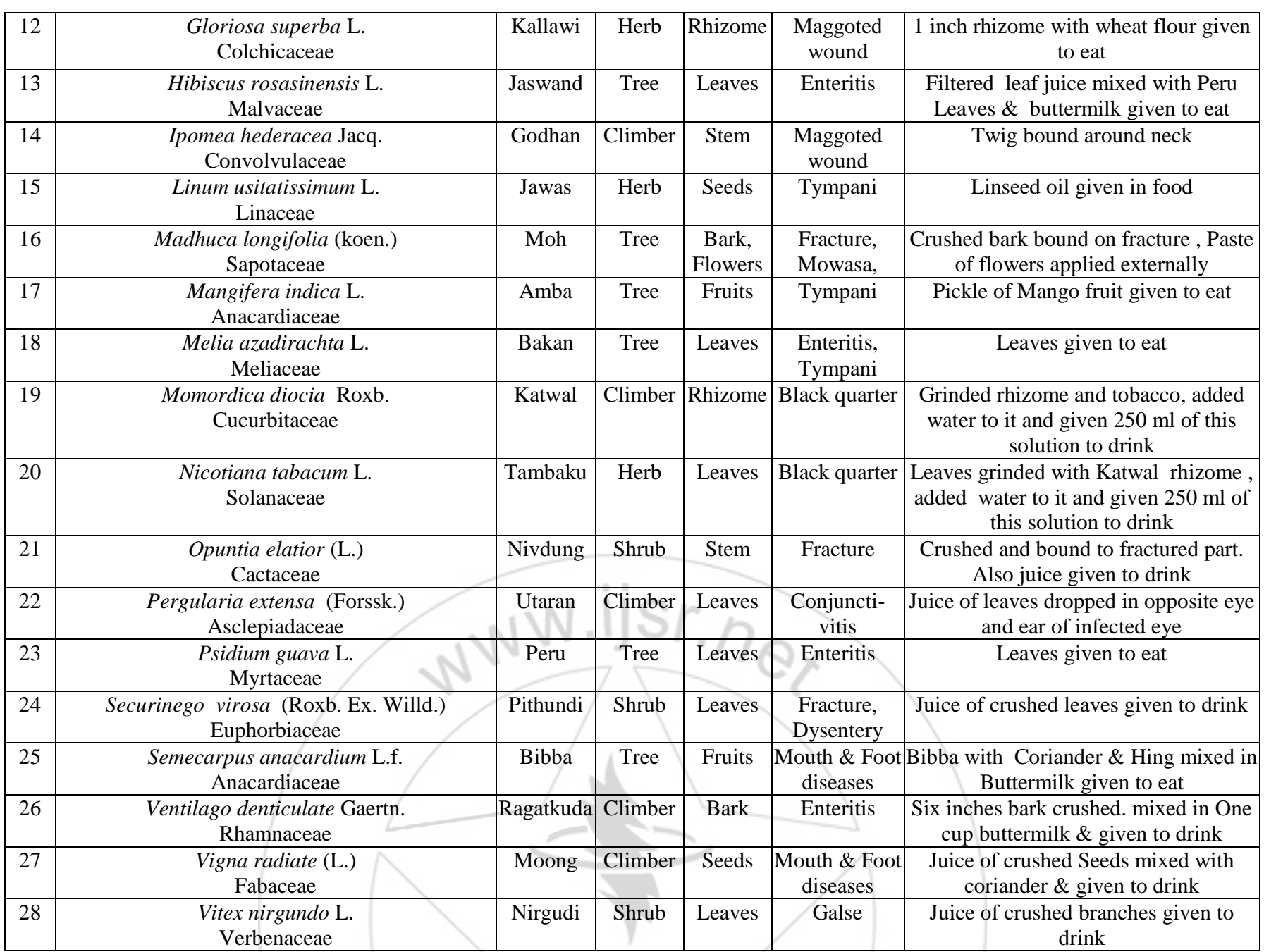
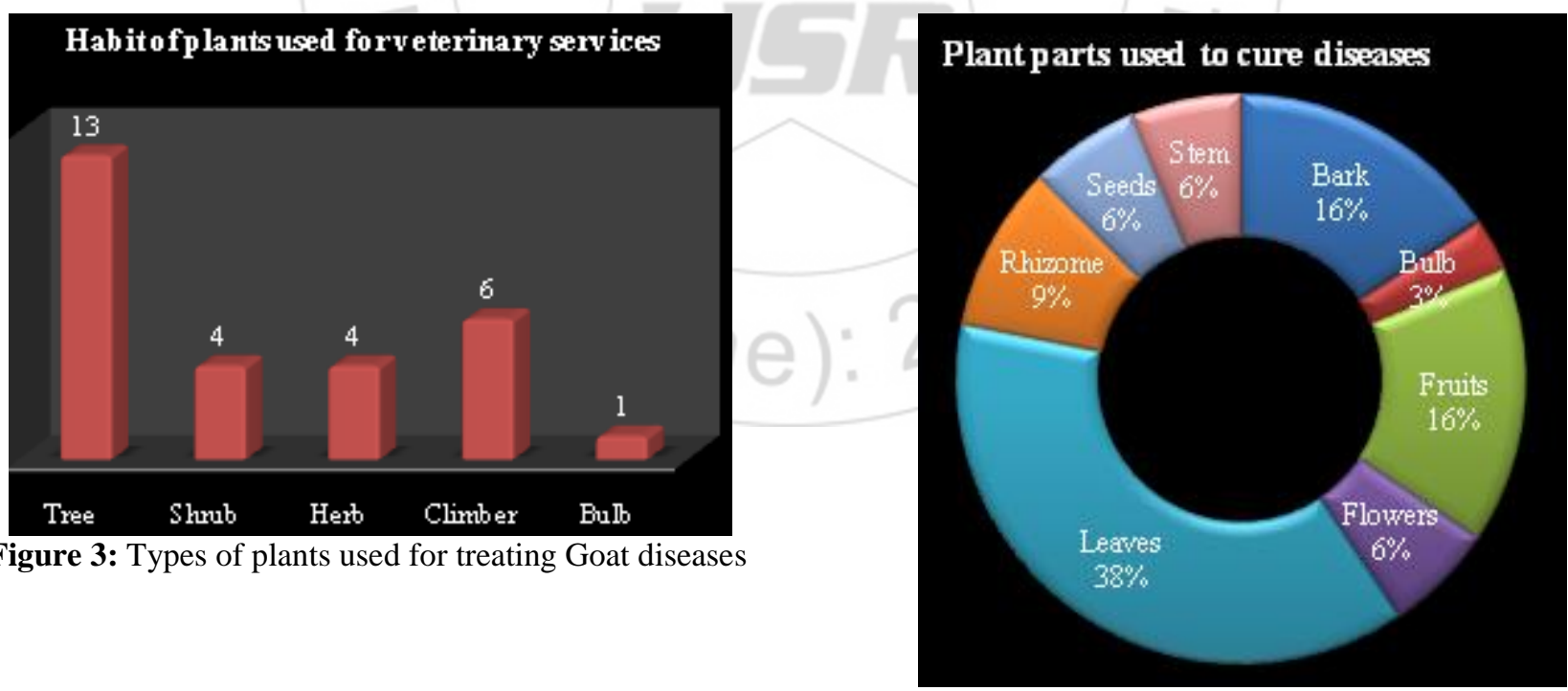

Figure 4: Percentage of plant parts used for treating Goat diseases 


\section{International Journal of Science and Research (IJSR) \\ ISSN (Online): 2319-7064}

Index Copernicus Value (2013): 6.14 | Impact Factor (2015): 6.391

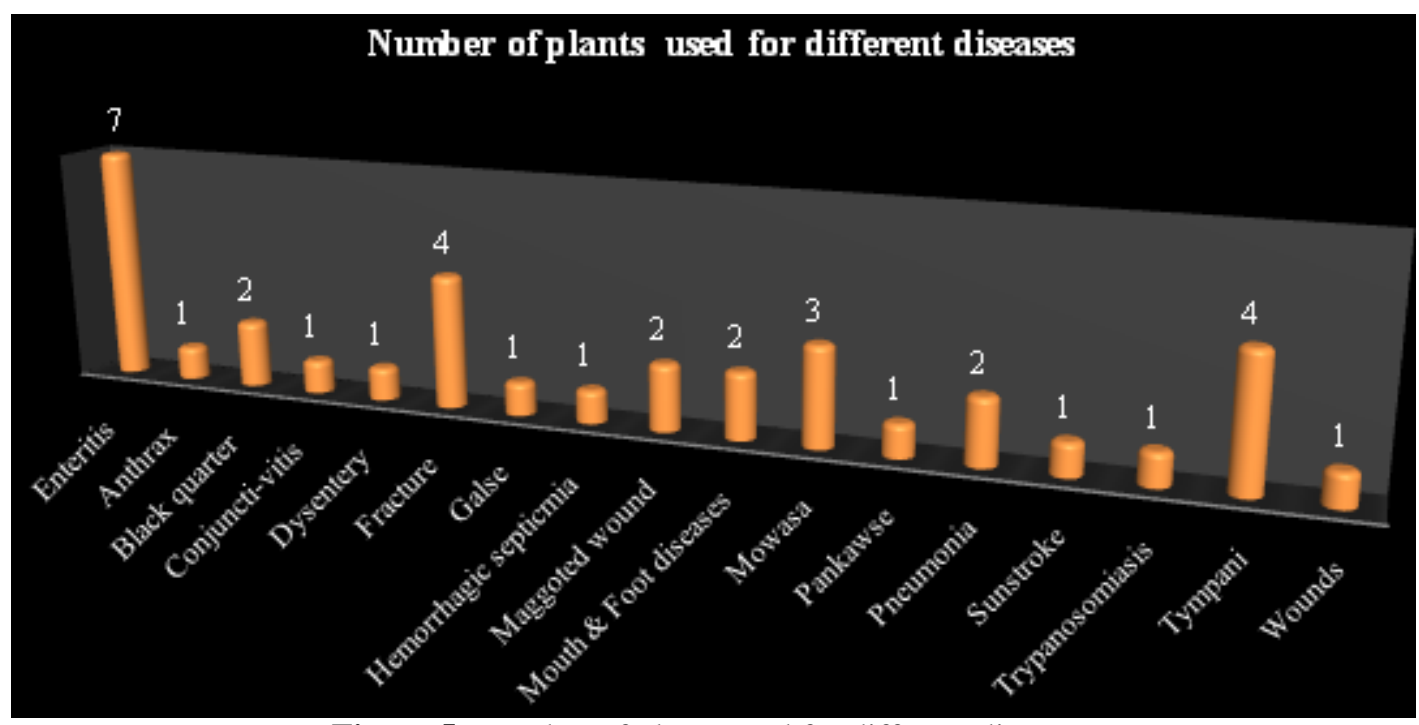

Figure 5: Number of plants used for different diseases

\section{Conclusion}

After reviewing the above mentioned studies of earlier workers the present investigators observed that only 06 species (Alianthus excelsa, Azadirachta indica, Semicarpus anacardium, Vitex negundo, Butea monosperma and Madhuca longifolia) from our recorded data were used in another regions also, while 22 species are used in Wardha district and plants belonging to family Anacardiaceae, Rutaceae and Meliaceae were frequently used. This study reveals that the leaves, roots, stems, bark, underground parts, flowers, fruits, etc. are used for curing the diseases However, all workers have observed the understanding of local people about ethno-veterinary uses of plants, their knowledge about ailments, method of preparation of medicine and the amount of appropriate doses for particular ailment. The plant parts used in specific diseases and their mode of treatment vary in different regions. But the common thing in all studies is, leaves were the most preferred part. In the opinion of present investigators, there is an urgent need to study the phyto-chemical, pharmacological and clinical aspects of ethno-veterinary plants for confirmation of their veterinary uses. Such collective work enriches the wealth of the traditional knowledge of medicinal plants and would explore potential for research and discovery of new medicines so as to cure the diseases of animals.

\section{Future Scope}

Twenty eight medicinal plants documented by the present investigators can be multiplied in order to meet the ethnoveterian uses by the local peoples in Wardha district. This can be achieved by creating awareness among villagers through local Government / Social agencies. The multiplication and conservation can easily be done on the field boundaries and barren land in villages.

\section{Acknowledgements}

We are highly obliged to Dr. Om Mahodaya, Principal and Dr. K.G.Dube, Head of Botany Department, Jankidevi Bajaj college of Science, Wardha, for providing the necessary laboratory and library facilities for this investigation. Also thankful to all those folk people and villagers who have provided information for this work.

\section{References}

[1] Malla B, Chhetri R, "Ethno-veterinary practices of some plant species by ethnic people of Parbat District, Nepal." Kathmandu University journal of Science, Engineering and Technology. 8(1),pp. 44-50, 2012

[2] Census -Socio-Economic review of Wardha district. 2013:4-8

[3] Pranjale A, Dube K, "Some wild fodder plants used for livestock by traditional shepherds in Wardha district." Proceeding of National conference on ethnobotanty. Pp. 76-79, 2013.

[4] Patil et al. "Ethnobotany of Buldhana District (Maharashtra: India): Plants used in veterinary medicine. Journalof Phytology . 2(12), pp. 2234,2010

[5] Shrivastava et al. "Documentation of herbal medicines used in treatment of diseases of goats (Cypris communis) in and around Gwalior (M.P.)." Indian Journal of Natural Products and Resources. 3(2), pp. 278-280, 2012

[6] Panda S, Dhal N. "Plants used as ethno-veterinary medicine by native people of in Nawrangpur District Odisha, India." World Journal of Pharmacy and Pharmaceutical Sciences. 3(7), pp. 787- 798, 2014

[7] Patil, Deshmukh "Traditional ethno-veterinary practices in Betul District(M.P.) India.” International Journal of Current Research in Life Sciences. 4(10), pp. 423-428, 2015.

[8] Singh, N. et al. "Flora of Maharashtra State Dicotyledonous Vol. I ." Botanical Survey of India, Calcutta, India.pp. 1-898, 2001

[9] Singh, N. et al. "Flora of Maharashtra State Dicotyledonous Vol.II." Botanical Survey of India, Calcutta, India. Pp. 1-1079, 2001 


\section{International Journal of Science and Research (IJSR) \\ ISSN (Online): 2319-7064}

Index Copernicus Value (2013): 6.14 | Impact Factor (2015): 6.391

\section{Author Profile}

Arati Pranjale - Ghushe - M.Sc. in botany from

Rashtrasant Tukadoji Maharaj Nagpur University,

Nagpur. From 14 years working in Shiksh Mandal,

Wardha in Community Development field. Worked as

Field officer in the project addressing the issue of Indoor air pollution in rural kitchen with ARTI, Pune \& SHELL Foundation, UK. Worked in the project -Insecticide resistance management for Cotton farmers with Central Institute for Cotton Research, Nagpur, At present working in the Scheme Community Development through Polytechnic by Ministry of Human Resource Development (MHRD), New Delhi.

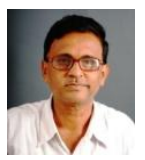

Dr. Kishor Dube, (M.Sc., Ph.D., B.Ed.), Ast. Prof. and Head of the Department of Botany, Jankidevi Bajaj College of Science, Wardha. Ph.D. Supervisor : Research areas: Cytogenetics, Medicinal plants, Ethnobotany and Plant Tissue Culture. Author of Ten books. Published 42 papers in National \& International Journals. Recipient of National Award by President of India.

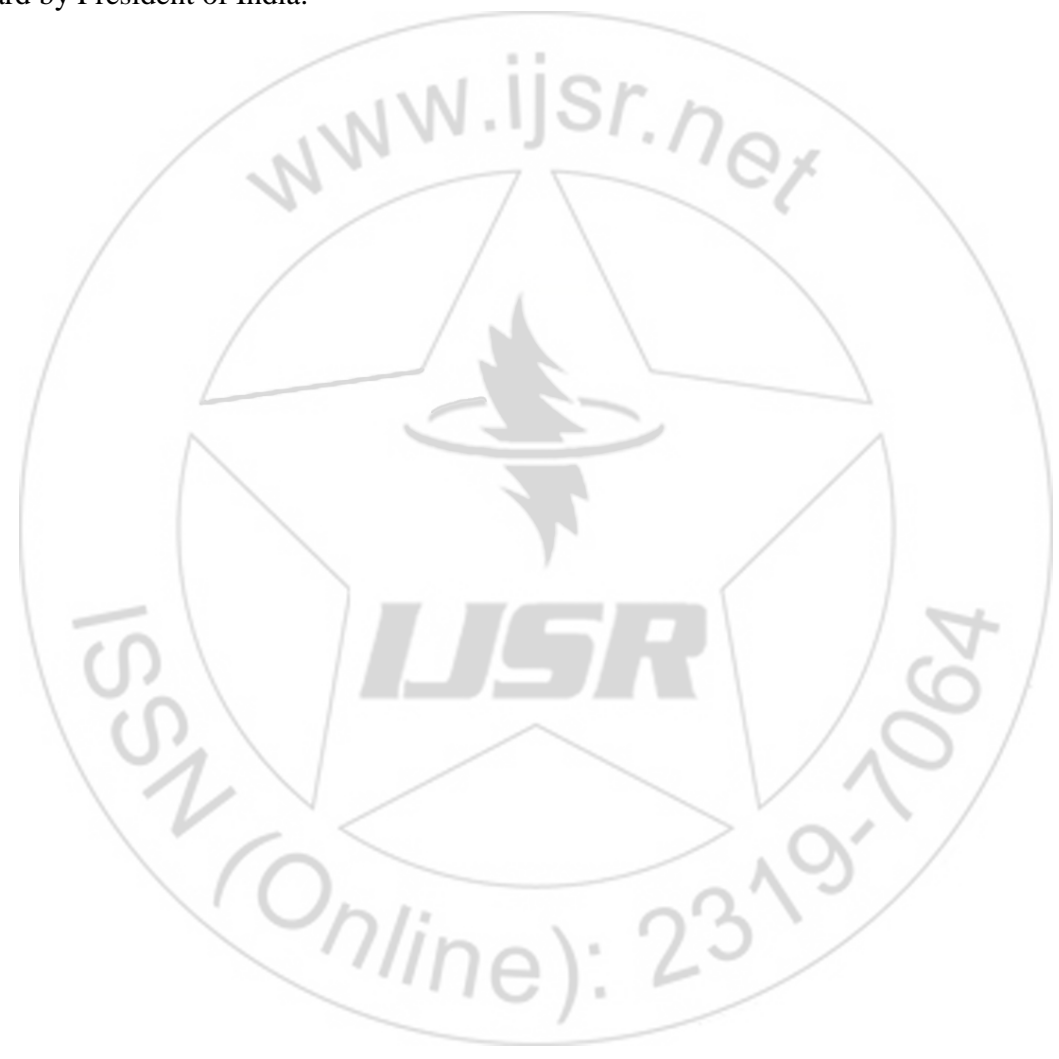

